\title{
Immune Thrombocytopenic Purpura As Sole Manifestation and Hemophagocytic Lypmhohistiocytosis As Sole Manifestation of Hepatitis a Virus Infection in Two Children*
}

\author{
İmmün Trombositopenik Purpuranın Tek Bulgu Olduğu ve \\ Hemofagositik Lenfohistiositozun Tek Bulgu Olduğu \\ İki Çocuk Olguda Hepatit A Virüs Enfeksiyonu
}

Zümrüt Şahbudak Bal', Semra Şen'1, Nihal Karadaş Özdemir², Katibe Başak Yıldız', Deniz Yılmaz Karapınar ${ }^{2}$, Fadıl Vardar ${ }^{1}$

' Department of Pediatric Infectious Diseases, Ege University School of Medicine, Izmir, Turkey

${ }^{2}$ Department of Hematology, Ege University School of Medicine, Izmir, Turkey

Abstract

Hepatitis A virus (HAV) infection is often asymptomatic or mildly symptomatic in pediatric population, the severity of the disease increases by age. Immune-mediated extrahepatic extrahepatic manifestations and hematologic complications are mainly reported in adults with acute and chronic hepatitis B and C. However, they are relatively rare in children with HAV infection. There are few available pediatric reports in English literature about autoimmune complications of HAV infection. We reported hematologic manifestations of HAV infection including hemophagocytic lymphohistiocytosis $(\mathrm{HLH})$ and immune thrombocytopenic purpura as sole manifestations of HAV infection therefore in patients with these hematologic disorders, HAV infection should be kept in mind in the differential diagnosis even if they are not jaundiced.

Keywords: Hematologic manifestation, hepatitis A, child
Özet

Hepatit A virüs (HAV) enfeksiyonu çocukluk çağında genellikle asemptomatik ya da hafif seyirlidir, yaş arttıkça hastalığın ciddiyeti artar. Ekstrahepatik immün-aracılı bulgular ve hematolojik komplikasyonlar genellikle yetişkinlerde, akut ve kronik hepatit B ve $C$ enfeksiyonlarının seyrinde bildirilmiştir. Çocukluk çağında oldukça nadirdir. İngilizce literatürde, çocuklarda hepatit A'nın otoimmün komplikasyonlarını bildiren olgu sunumları oldukça azdır. Bu çalışmada, immün trombositopenik purpura ve hemofagositik lenfohistiositoz (HLH) bulguları ile HAV tanısı alan iki çocuk olgu sunulmuştur, bu nedenle bu hastalıklarda tanı anında sarılık bulgusu olmasa da HAV enfeksiyonu akılda tutulmalıdır.

Anahtar Kelimeler: Hematolojik bulgu, hepatit A, çocuk 


\section{Introduction}

Hepatitis A virus (HAV) infection in children is typically an acute, self-limited disease associated with general, nonspecific symptoms, such as fever, malaise, anorexia, and vomiting (1). In children younger than 5 years, HAV infection is usually inapparent; whereas, most adults present with symptoms, with the severity of the disease increasing with the age $(1,2)$. Autoimmune complications such as idiopathic thrombocytopenic purpura (ITP), aplastic anemia, and hemophagocytic lymphohistiocytosis $(\mathrm{HLH})$ have been rarely reported in children (3). Hepatitis A is a vaccine-preventable disease but it was not included in the national vaccination programme of Turkey before November 2012. Herein, we report hematologic manifestations associated with HAV infection in two pediatric patients without jaundice.

\section{Case Reports}

A Case $1 \mathrm{~A}$ previously healthy eleven year old boy admitted to our hospital with the complaints of bleeding in the mouth from oral mucosa, bruising all over the body, and petechial rash. Past history did not suggest an underlying liver disease or hematologic disorder. Several purpuric, petechial lesions and ecchymosis were detected on physical examination in his mouth, upper and lower extremities. His liver was $2 \mathrm{~cm}$ palpable, and spleen was not palpable. Physical examination of the other systems had normal findings. Laboratory investigations revealed elevated liver enzyme levels (AST 2512 $\mathrm{U} / \mathrm{L}$, ALT $2248 \mathrm{U} / \mathrm{L}$ ), with the normal levels of alkaline phosphatase, total and direct bilirubin, gamma glutamyl transferase, ferritin, total protein, albumin, prothrombin time, activated partial thromboplastin time, fibrinogen and D- dimer. Complete blood cell count showed that hemoglobin was $11 \mathrm{~g} / \mathrm{dL}$, white blood cell count $2870 / \mathrm{mL}$ with a differential analysis of $41 \%$ neutrophil, $34 \%$ lymphocyte, and $18 \%$ monocyte, platelet count $10000 / \mathrm{mm}^{3}$, and reticulocyte count of $0.8 \%$. Direct and indirect Coombs tests, antinuclear antibody, antidsDNA, anticardiolipin and antiphospholipid IgM and IgG antibodies were negative. Quantitative serum immunoglobulins and complement ( $\mathrm{C} 3$ and $\mathrm{C4}$ ) levels were normal. Examination of the bone marrow aspiration revealed normocellular marrow with trilineage hematopoiesis and megakaryocytic hyperplasia with many mature and immature megakaryocytes and no hemophagocytosis. His bone marrow aspiration showed increased megakaryocytes so we established the diagnosis of ITP and intravenous immunoglobulin (IVIG ) with a $1 \mathrm{~g} / \mathrm{kg}$ dose was given for two consequence days, on the third day platelet counts was $51.400 / \mathrm{mm}^{3}$, and platelet counts returned to normal values $\left(369.000 / \mathrm{mm}^{3}\right)$ in seven days. To investigate the etiology of ITP, viral serologic tests were performed and found positive results for anti-HAV IgM antibody, and negati- ve results for anti-HAV IgG, hepatitis B and C, Epstein-Barr virüs, cytomegalovirus, toxoplasma, rubella, and parvovirus B19. He developed anti-HAV IgG, and serum anti-HAV IgM disappeared six weeks later. One month later after admission liver functions returned to normal levels. As a result of these findings, ITP as the sole manifestation of acute hepatitis A infection was diagnosed in our patient.

Case 2 A previously healthy 14- month girl referred to our hospital with prolonged fever, cough, loss of appetite, and malaise. Her physical examination revealed pallor, abdominal distension. The liver and spleen were both palpable 8 and 10 $\mathrm{cm}$ below the costal margin. She was not jaundiced and other system examinations had normal findings. She had a history of one sibling's death and there was no consanguinity between her parents. There was no family history of immune or hematologic disorders. Peripheral blood counts showed pancytopenia ( white blood cell $2.26 \times 10^{3} / \mathrm{mL}$; hemoglobin $7.57 \mathrm{~g} / \mathrm{dL}$; hematocrit $21 \%$; platelets $51 \times 10^{3} / \mathrm{mL}$ ). Coagulation studies revealed a prothrombin time of 13 seconds, active partial thromboplastin time of 29.5 seconds, a fibrinogen level of $130 \mathrm{mg} / \mathrm{dL}$, and a dimer level over $4500 \mu / \mathrm{mL}$. Blood chemistry revealed elevated liver enzyme levels (AST $546 \mathrm{U} / \mathrm{L}$, ALT $587 \mathrm{U} / \mathrm{L}$ ), C-reactive protein $(13.6 \mathrm{mg} / \mathrm{dL})$, lactate dehydrogenase enzyme (LDH) (2472 $\mathrm{mg} / \mathrm{dL})$, alkaline phosphatase $(763 \mathrm{mg} / \mathrm{dL})$, triglyceride $(506$ $\mathrm{mg} / \mathrm{dL})$, ferritin $(16.600 \mu \mathrm{g} / \mathrm{dL})$, and normal serum level levels of total and direct bilirubin, total protein and albumin, and blood urine nitrogen. Bone marrow aspiration showed hemophagocytosis. Hepatosplenomegaly was the main finding on ultrasonography. Her laboratory findings revealed pancytopenia, elevated triglyceride, and ferritin levels, hypofibrinogenemia, and hemophagocytosis in bone marrow aspiration, and these findings were fulfilled the diagnostic criteria of hemophagocytic lymphohistiocytosis (HLH). For the etiology, viral serologic studies were performed and found positive results for anti-HAV $\operatorname{lgM}$, and negative results for anti- HAV IgG, hepatitis B and C, Epstein-Barr virus, cytomegalovirus, rubella, and Parvovirus B19. Absence of the parental consanguinity and a known family history made the diagnosis of secondary HLH likely. Due to high endemicity in the South eastern region of Turkey and also her young age, we performed her genetic analysis and genetic defect was not detected in PRF 1, SNX 11, UNC13D genes for primary (familial) HLH. She was treated with steroid, and IVIG at a dose of $0.4 \mathrm{mg} / \mathrm{kg} /$ day was prescribed for 5 days. Ferritin level increased up to $15.900 \mu \mathrm{g} / \mathrm{dL}$ again, hypofibrinogenemia persisted $(97 \mathrm{mg} / \mathrm{dL})$, and her physical examination revealed hepatosplenomegaly. Her general condition did not improve despite steroid and IVIG therapy so we started cyclosporine. Her laboratory abnormalities improved dramatically after the onset of the cyclosporine. She was in good health at the $6^{\text {th }}$ month of follow up. 


\section{Discussion}

Hepatitis A infection is usually a self-limited disease conferring lifelong immunity (1-3). HAV infection associated with hematologic complications including severe aplastic anemia, virus associated hemophagocytic syndrome (VAHS), postinfectious thrombocytopenic purpura, and immune thrombocytopenic purpura (4). Immune-mediated extrahepatic manifestations, and hematologic complications are mainly reported in adults with acute and chronic hepatitis B and C. However they are relatively rare in children with hepatitis $A(3,4)$. Thrombocytopenia may be a result of bone marrow depression, virus-associated hemophagocytic syndrome, immune-mediated peripheral destruction of platelets or increased platelet consumption associated with disseminated intravascular coagulopathy (3). We could find only seven pediatric patients with immune thrombocytopenia associated with HAV infection previously reported in English medical literature (3,5-10). Two of seven patients were not jaundiced on admission to the hospital, and our patient was the third (3-5). Ertem et al. (3) reported a 5-year old girl whose initial manifestation was immune thrombocytopenia. Tanır et al. (9) reported a five year old boy with immune thrombocytopenia as the sole manifestation of HAV infection as our patient. In our patient we established the diagnosis with increased megakaryocytes in bone marrow aspiration suggested peripheral destruction of platelets, no hemophagocytosis in bone marrow and response to IVIG therapy. Immune thrombocytopenic purpura is usually a benign and self- limiting hematologic complication of HAV infection. Our patient had good response to IVIG therapy and thrombocytopenia resolved in seven days. HAV infection should be considered in the differential diagnosis of immune thrombocytopenic purpura in children without jaundice.

$\mathrm{HLH}$ and aplastic anemia are severe hematologic complications of HAV infections. Secondary HLH consists of a variety of conditions associated with infection, malignancy, autoimmune disorders, and drugs (11). Virus-induced HLH is a fatal disease and frequently complicates multiple organ failure or disseminated intravascular coagulopathy. The identification of an infectious organism does not help to discriminate between genetic and acquired forms of $\mathrm{HLH}$, since also most episodes in genetic HLH are triggered by infections (12). In our patient we established the diagnosis of $\mathrm{HLH}$ with the $\mathrm{HLH}$ 2004 guideline, and we treated her with IVIG, steroid and cyclosporine. As a consequence of a history of one sibling's death and high endemicity in that region of Turkey, we performed genetic analysis for primary $\mathrm{HLH}$, but no genetic disorder was found. Bay et al. (13) described two previously healthy pediatric patients and our patient was the third, they responded to IVIG therapy, and hematological parameters turned to normal on third and fifth days. Our patient did not respond to IVIG and steroid therapy so the therapy switched to cyclosporine. Her hematological parameters turned to normal values at $12^{\text {th }}$ day but triglyceride and ferritin levels which show activation, turned to normal levels after cyclosporine therapy onset.

Although many viral infections such as hepatitis B, parvovirus and Epstein-Barr virus are associated with extrahepatic autoimmune phenomena, such manifestations are rare during the course of acute HAV infection. Also extrahepatic complications are rare in children, serious complications may cost mortality and they serve as a source of infection for adults. The main manifestation of HAV infection on admission is jaundice, but these hematologic complications can initially manifest without jaundice; therefore, the patients presented with these hematologic disorders should be investigated for HAV infection.

There is no conflict of interest in relation to this article

Informed Consent: Could not be obtained because the patient coould not be follow-up.

Peer-review: Externally peer-reviewed.

Author Contributions: Concept - ZŞB; Design - ZŞB; Supervision FV, DYK; Collection and/or Processing - ZŞB; Literature Review - ZŞB; Writing - ZŞB; Critical Review - DYK, FV; all authors contributed to patient follow-up.

Conflict of Interest: The authors have not reported a conflict of interest.

Financial Disclosure: The authors declared that they did not receive financial support.

\section{References}

1. Quirós-Tejeira RE. Overview of hepatitis A virus infection in children: Uptodate. Available at http://www.uptodate.com/contents/overview-ofhepatitis- a-virus infection- in children? source=search_result\&search=Hepatitis+A\&selected Title $=$ 2\%7E150. Accesed March 21, 2013.

2. Kurkela S, Pebody $R$, Kafatos $G$, et al. Comparative hepatitis A seroepidemiology in 10 European countries. Epidemiol Infect 2012;140:2172-81. [CrossRef]

3. Ertem D, Acar Y, Pehlivanoglu E. Autoimmune complications associated with hepatitis A virus infection in children. Pediatr Infect Dis J 2001;20:809-11. [CrossRef]

4. Chatzimichael A, Schoina M, Arvanitidou V, Ramatani A, Mantadakis E. Hematologic complications of hepatitis A: another reason for implementation of anti-HAV vaccination. J Pediatr Hematol Oncol 2008;30:562. [CrossRef]

5. Avci Z, Turul T, Catal F, et al. Thrombocytopenia and emperipolesis in a patient with hepatitis a infection. Pediatr Hematol Oncol 2002; 19:67-70. [CrossRef]

6. Choulot JJ, Coquard JL, Pariente A, Saint-Martin J, Mensire A. Hepatitis A and immune thrombocytopenic purpura. Arch Pediatr 1994;1:213-4.

7. Scott JX, Gnananayagam EJ, Gupta S, Simon A, Mukhopadhya A. Thrombocytopenic purpura as initial presentation of acute hepatitis A. Indian J Gastroenterol 2003;22:192-3. [CrossRef]

8. Shenoy R, Nair S, Kamath N. Thrombocytopenia in hepatitis A--an atypical presentation. J Trop Pediatr 2004;50:241-2. [CrossRef] 
Şahbudak Bal et al.

9. Tanir G, Aydemir C, Tuygun N, Kaya O, Yarali N. Immune thrombocytopenic purpura as sole manifestation in a case of acute hepatitis A. Turk J Gastroenterol 2005; 16:217-9. [CrossRef]

10. Venkataravanamma $P$, Rau AT. Severe thrombocytopenia in association with hepatitis A. Indian Pediatr 2004;41:1178-9. [CrossRef]

11. Park HS, Kim DY, Lee JH, et al. Clinical features of adult patients with secondary hemophagocytic lymphohistiocytosis from causes other than lymphoma: an analysis of treatment outcome and prognostic factors. Ann Hematol 2012;91:897-904. [CrossRef]
12. Janka GE. Hemophagocytic syndromes. Blood Rev 2007;21:245-53. [CrossRef]

13. Bay A, Bosnak V, Leblebisatan G, Yavuz S, Yilmaz F, Hizli S. Hemophagocytic lymphohistiocytosis in 2 pediatric patients secondary to hepatitis A virüs infection. Pediatr Hematol Oncol 2012;29:211-4. [CrossRef] 